\title{
PRODUKSI GLUKOSAMIN BIJI BUAH SIWALAN (BORASSUS FLABELLIFER) MENGGUNAKAN PRE-TREATMENT MAE (MICROWAVE ASSISTED EXTRACTION)
}

\author{
Glucosamine Production from a Siwalan Seeds (Borassus flabellifer) \\ Using Pre-Treatment MAE (Microwave Assisted Extraction) \\ Nur Lailatul Rahmah ${ }^{1,2 *}$, Sisca Ikke Wulandari ${ }^{1}$, Chastita Hikmatun Nisa ${ }^{1}$, \\ Dimas Rosi Syaiful Rohman ${ }^{1}$ \\ ${ }^{1}$ Jurusan Teknologi Industri Pertanian - Fakultas TeknologiPertanian - Universitas Brawijaya \\ ${ }^{2}$ Grup Riset Agroindustri Palma-Universitas Brawijaya \\ Jalan Veteran, Malang - 65145 \\ *Penulis Korespondensi: email: : nur_laila@ub.ac.id
}

Disubmit: 12 November 2018 Direvisi: 2 April 2019 Diterima: 23 Mei 2019

\begin{abstract}
ABSTRAK
Biji buah siwalan diketahui memiliki susunan isomer karbohidrat bernama $\beta$-pyranosil yang dapat diidentikkan sebagai glukosamin. Glukosamin banyak diproduksi dari sumber hewani yang dapat memberikan efek samping bagi seseorang yang intolerant terhadap protein hewani, sehingga diperlukan pengembangan glukosamin nabati seperti biji buah siwalan. Produksi glukosamin dapat ditingkatkan dengan menambahkan prekursor garam ammonium. Selain itu, ekstraksi menggunakan pre-treatment Microwave Assisted Extraction (MAE) terbukti dapat meningkatkan rendemen dan kualitas ekstrak. Oleh karena itu, penelitian ini dilakukan untuk mengetahui perlakuan terbaik dalam produksi glukosamin melalui pre-treatment MAE berdasarkan variasi rasio bahan : prekursor dan lama waktu aplikasi MAE. Rancangan percobaan pada penelitian ini adalah Rancangan Acak Kelompok dengan 2 faktor perlakuan yaitu rasio bahan : prekursor $\mathrm{NH}_{4} \mathrm{Cl}$ (b/v) 3 level (1:2 ; 1:3; dan 1:4) serta waktu aplikasi MAE 3 level (5 menit; 10 menit; dan 15 menit) dengan 2 kali ulangan. Perlakuan terbaik dari hasil ekstraksi glukosamin biji buah siwalan terdapat pada perlakuan rasio bahan : prekursor $\mathrm{NH}_{4} \mathrm{Cl}$ (1:2) dan waktu ekstraksi 10 menit dimana ekstrak glukosamin terbaik memiliki kadar 380,33 ppm, pH 4,2, dan rendemen 13,69\%
\end{abstract}

Kata kunci : Ammonium Klorida, Kadar Glukosamin, Prekursor $\mathrm{NH}_{4} \mathrm{Cl}$, Waktu MAE

\begin{abstract}
Siwalan seeds are known to have composition of carbohydrate isomers called $\beta$-pyranosil which can be identified as glucosamine. Glucosamine is widely produced from animal sources which can provide side effects for someone who intolerance to animal's protein, so it is necessary to develop vegetable glucosamine such as from siwalan seeds. Glucosamine production can be increased by adding ammonium salt precursors. In addition, extraction using pre-treatment Microwave Assisted Extraction (MAE) was proven to increase yield and quality of extract. Therefore, this study was intended to determine the best treatment for glucosamine production from siwalan seeds through MAE pre-treatment based on variations of material ratio: precursor and the length of MAE time. The experimental design in this study was a randomized block design with 2 treatment factors, namely material ratio: precursor $\mathrm{NH} 4 \mathrm{Cl}$ (b/v) 3 levels (1:2; 1:3; and 1:4) and 3 levels of MAE time (5 minutes; 10 minutes; and 15 minutes) with 2 repetitions. The best treatment of glucosamine extracts of a siwalan seeds was on treatment material ratio: precursor $\mathrm{NH} 4 \mathrm{Cl}(\mathrm{b} / \mathrm{v})(1: 2)$ and extraction time 10 minutes where the best extract level of glucosamine was $380.33 \mathrm{ppm}, \mathrm{pH}$ 4.2, and yield $13.69 \%$
\end{abstract}

Keywords : Ammonium Chloride, Glucosamine Content, Precursor NH4Cl, MAE Time 
Jurnal Teknologi Pertanian Vol. 20 No. 2 [Agustus 2019] 139-144

Produksi Glukosamin Biji Buah Siwalan (Borassus Flabellifer) [Rahmah dkk]

\section{PENDAHULUAN}

Tanaman Siwalan merupakan salah satu jenis dari palmae yang dapat tumbuh di daerah kering dan pesisir. Di Indonesia, tanaman siwalan terutama tumbuh di bagian Timur Pulau Jawa, Madura, Bali, Nusa Tenggara Barat, dan Nusa Tenggara Timur. Di pulau Jawa dan Madura luas areal persebaran tanaman siwalan mencapai 15000 ha (Karmawati et al., 2014). Tanaman siwalan memiliki potensi yang cukup tinggi untuk dikembangkan. Salah satu bagian tanaman siwalan yang berpotensi tersebut yakni biji buah siwalan. Biji buah siwalan memiliki kandungan gula, gula reduksi, protein, mineral, fosfor, besi, vitamin C dan B1 (Rahmah et al., 2016). Berdasarkan penelitian Keerthi et al. (2009), ekstrak tepung biji buah siwalan memiliki susunan isomer karbohidrat yang bernama Tetraglycoside spirostane, yang mengandung residu berupa tiga a-rhamnosyl dan satu $\beta$-pyranosil. Sesuai dengan perbandingan spectra data, bahwasannya $\beta$-pyranosil memiliki struktur yang dapat diidentikkan dengan glukosamin (glucasaminosyl). Berdasarkan penelitian Rahmah et al. (2016) didapat kandungan glukosamin pada biji buah siwalan sebesar 964 ppm menggunakan ekstraksi dengan $\mathrm{NH}_{4} \mathrm{Cl}$ 1,59 M dan waktu perendaman 15 jam. Selain itu, penggunaan precursor Ammonium klorida 4,5 M dan lama perendaman $12 \mathrm{jam}$ pada suhu $70{ }^{\circ} \mathrm{C}$ menghasilkan kadar glukosamin biji siwalan sebesar 1418,5 ppm; pH sebesar 4,47; rendemen sebesar $0,450 \%$; dan Loss on Drying sebesar 0,242\% (Hajar, 2016).

Produksi glukosamin pun mulai dikembangkan dan menggunakan berbagai macam bahan baku baik dari bahan hewani maupun nabati. Glukosamin banyak diproduksi sebagai prekusor obat untuk penyakit tulang. Glukosamin banyak diproduksi dari limbah cangkang crustceae dan antropoda, dimana sebagian orang intolerant terhadap produk yang berasal dari hewani. Bagi beberapa orang yang memiliki alergi terhadap produk hewani akan merasakan efek samping berupa rasa mual, diare, susah pernafasan, gatal, bengkak, kram perut, sesak nafas, kesemutan pada tangan, kaki, bibir, ataupun kulit kepala (Jarti dan Trisno, 2017). Oleh karena itu, diperlukan pengembangan glukosamin yang berasal dari nabati seperti biji buah siwalan.
Ekstraksi biji buah siwalan ini menggunakan pre-treatment metode microwave assisted extraction. Metode ini memanfaatkan radiasi gelombang mikro untuk memanaskan pelarut secara efektif sehingga dapat menarik kandungan pada sampel kedalam pearut (Deo et al., 2015). Metode MAE dapat membantu meningkatkan kadar ekstrak dalam waktu ekstraksi dan rasio pelarut yang lebih rendah dibanding dengan konvensional (Langat et al., 2011). Terdapat beberapa faktor kritis yang mempengaruhi ekstraksi glukosamin dengan gelombang mikro yakni perbandingan antara rasio bahan dan pelarut serta lama ekstraksi. Secara umum, semakin besar perbandingan rasio bahan dan pelarut maka akan meningkatkan jumlah senyawa yang diekstrak (Winata dan Yunianta, 2015). Meningkatnya waktu ekstraksi juga akan meningkatkan senyawa yang diekstrak (Mandal et al., 2007). Metode ini diharapkan mampu menghasilkan glukosamin dengan kadar yang tinggi.

\section{METODE}

Bahan baku yang digunakan dalam penelitian ini yaitu biji buah siwalan berwarna putih, bening, dan tekstur tidak keras yang diperoleh dari penjual yang berada di kota Malang, Jawa Timur, dengan umur 3 minggu. Bahan pendukung yang digunakan antara lain ammonium klorida, aquades $(\mathrm{pH}$ $=7$ ), etanol 95\%, dan glucosamine hidrochloride SIGMA-ALDRICH standar, dan asam asetat glasial.

Alat yang digunakan dalam penelitian produksi glukosamin dari biji buah siwalan meliputi microwave, pisau (stainless steel), timbangan, oven (Heraeus), loyang, ayakan 60 mesh, erlenmeyer $50 \mathrm{ml}$ (pyrex), kertas saring, neraca analitik (AND/Gr-200), labu takar (pyrex), dan hot plate and stirrer (Labinco). Selain itu, peralatan yang digunakan pada analisis penelitian meliputi tabung reaksi (pyrex), spektrofotometer (Genesys $10 \mathrm{UV}$ ), pH meter (Eutech Ecosa), pipet tetes, pipet ukur, erlenmeyer $50 \mathrm{ml}$ (pyrex), botol film negatif, dan beaker glass (pyrex).

\section{Rancangan Percobaan}

Proses ekstraksi disusun menggunakan Rancangan Acak Kelompok (RAK) dengan 2 faktor perlakuan dimana faktor pertama menggunakan rasio bahan : pelarut $(b / v)$ 
yang terdiri atas 3 level (1:2, 1:3, dan 1:4)) dan faktor kedua yaitu lama waktu MAE terdiri atas 3 level (5, 10, dan 15 menit). Masingmasing perlakuan akan diulang sebanyak 2 kali sehingga didapatkan 18 satuan percobaan.

\section{Pelaksanaan Penelitian}

Adapun tahapan proses ekstraksi biji pinang dimulai dari biji buah siwalan dikupas dan dicuci hingga bersih. Dihitung bobot awal dari biji buah siwalan basah. Biji buah siwalan tersebut dipotong menjadi ukuran yang lebih kecil. Biji buah siwalan selanjutnya dihaluskan menggunakan blender. Biji buah siwalan ditimbang 25 g sebanyak 18 kali sesuai dengan semua perlakuan. Biji buah siwalan halus kemudian dimasukkan pada beaker glass dan ditambahkan dengan $\mathrm{NH}_{4} \mathrm{Cl} 4,5 \mathrm{M}$ sesuai volume percobaan yakni $1: 2 ; 1: 3 ; 1: 4$, serta diaduk secara merata (25 g : $50 \mathrm{ml} ; 25 \mathrm{~g}$ : $75 \mathrm{ml}$; dan $25 \mathrm{~g}$ : $100 \mathrm{ml})$. Beaker glass tersebut kemudian dimasukkan dalam microwave dengan daya 100 watt pada suhu $55^{\circ} \mathrm{C}$ sesuai waktu rancangan penelitian yakni 5 menit, 10 menit, dan 15 menit. Biji buah siwalan halus tersebut kemudian direndam aquades $100 \mathrm{ml}$ selama 4 jam. Setelah itu, biji buah siwalan halus dan filtrat siwalan dipisahkan menggunakan kertas saring. Filtrat siwalan kemudian dilakukan perhitungan rendemen, analisis $\mathrm{pH}$, dan analisis kadar glukosamin untuk menentukan perlakuan terbaik.

\section{HASIL DAN PEMBAHASAN}

\section{Kadar Glukosamin}

Hasil analisis sidik ragam (ANOVA) menunjukkan bahwa faktor rasio bahan : pelarut dan waktu ekstraksi memberikan pengaruh signifikan terhadap kadar glukosamin. Uji lanjut DMRT menunjukkan bahwa masing-masing perlakuan pada kedua faktor memberikan pengaruh yang signifikan terhadap kadar glukosamin yang telah dihasilkan. Gambar 1 menunjukkan kadar glukosamin yang dihasilkan antara 72 ppm sampai 380,33 ppm. Kadar glukosamin terbesar terdapat pada perlakuan rasio 1:2 dan lama ekstraksi 10 menit. Rasio bahan : pelarut sebesar 1:2 telah dapat membentuk senyawa glukosamin secara optimal. Pada rasio tersebut, jumlah ion $\mathrm{NH}_{2-}$ memiliki jumlah yang sebanding dengan gugus $\mathrm{OH}$ - yang akan digantikan pada molekul glukosa. Namun, semakin tinggi volume pelarut yang diberikan maka jumlah mol pelarut semakin besar dan jumlah ion $\mathrm{NH}_{2}$ semakin banyak. Hal ini memungkinkan terjadinya kondisi jenuh sehingga ion $\mathrm{NH}_{2-}$ yang berikatan dengan glukosa terlepas dan menyebabkan kadar glukosamin yang dihasilkan pada rasio 1:3 dan 1:4 semakin menurun. Waktu ekstraksi menggunakan metode microwave 10 menit menghasilkan kadar tertinggi sebesar 380,33 ppm. Hal ini terjadi karena dengan waktu ekstraksi 5 menit belum memberikan kesempatan ion $\mathrm{NH}_{2}$ bereaksi sempurna dengan glukosa pada biji buah siwalan. Akan tetapi waktu ekstraksi dengan lama 15 menit akan menyebabkan ikatan antara glukosa dan ion $\mathrm{NH}_{2-}$ terlepas sehingga menurunkan kadar glukosamin. Selain itu, waktu pemanasan yang terlalu lama dapat mendegradasi senyawa glukosamin yang dihasilkan. Hal ini sejalan dengan penelitian Farida dan Nisa (2015) tentang antosianin yang menunjukkan bahwa dengan rasio 1:20 dan waktu ekstraksi dengan metode microwave selama 10 menit menghasilkan kadar antosianin limbah kulit manggis sebesar 177,56 ppm kemudian menurun pada rasio 1:30, 1:40 dan waktu ekstraksi 15 menit.

\section{pH Ekstrak Glukosamin}

Hasil perhitungan ANOVA menunjukkan bahwa masing-masing perlakuan yaitu rasio bahan : pelarut dan waktu MAE tidak memberikan pengaruh signifikan terhadap $\mathrm{pH}$ yang dihasilkan. Hal ini diduga jumlah ion $\mathrm{H}^{+}$yang ada pada larutan glukosamin jumlahnya sama. Hal ini sesuai dengan penelitian Horn dan Walker (2009) bahwa penambahan konsentrasi pelarut ammonium klorida mempengaruhi $\mathrm{pH}$ glukosamin dimana semakin banyak ion amina yang dihasilkan oleh garam ammonium maka nilai pH dari ekstrak glukosamin akan meningkat. Berdasarkan Gambar 2 diketahui bila nilai rerata $\mathrm{pH}$ berkisar antara 4,2 sampai 4,9. Prekursor garam ammonium yang berasal dari asam kuat (ammonium sulfat dan ammonium klorida), cenderung menghasilkan ekstrak glukosamin dengan nilai $\mathrm{pH}$ yang lebih rendah. Hal ini sesuai dengan pernyataan Cargill Incorporated (2006) bahwa nilai $\mathrm{pH}$ glukosamin standar kisaran 3-5. pH glukosamin bersifat asam karena diduga pada saat reaksi prototropic berlangsung pada 
Jurnal Teknologi Pertanian Vol. 20 No. 2 [Agustus 2019] 139-144

Produksi Glukosamin Biji Buah Siwalan (Borassus Flabellifer) [Rahmah dkk]

Tabel 1. Penentuan perlakuan terbaik

\begin{tabular}{ccccccccc}
\hline \multirow{2}{*}{$\begin{array}{c}\text { Perbandingan } \\
\text { rasio bahan : } \\
\text { pelarut }\end{array}$} & $\begin{array}{c}\text { Lama } \\
\text { MAE }\end{array}$ & \multicolumn{3}{c}{ Derajat kerapatan } & \multicolumn{3}{c}{ Luas Kerapatan } & Keterangan \\
\cline { 5 - 9 } & (menit) & Kadar & Rendemen & pH & L1 & L2 & Lmaks & \\
\hline $1: 2$ & 5 & 0,1893 & 0,1892 & 0,8842 & 0,434 & 0,083 & 0,203 & \\
$1: 3$ & 5 & 0,2594 & 0,2593 & 0,8750 & 0,444 & 0,071 & 0,185 & \\
$1: 4$ & 5 & 0,1762 & 0,1760 & 0,8571 & 0,499 & 0,089 & 0,206 & \\
$\mathbf{1 : 2}$ & $\mathbf{1 0}$ & $\mathbf{1}$ & $\mathbf{1}$ & $\mathbf{1}$ & $\mathbf{0 , 0 8 1}$ & $\mathbf{0 , 0 0 6}$ & $\mathbf{0 , 0 0 0}$ & Terbaik \\
$1: 3$ & 10 & 0,7020 & 0,7020 & 0,9767 & 0,248 & 0,020 & 0,075 & \\
$1: 4$ & 10 & 0,3953 & 0,3952 & 0,8936 & 0,445 & 0,060 & 0,151 & \\
$1: 2$ & 15 & 0,3427 & 0,3426 & 0,9545 & 0,413 & 0,060 & 0,164 & \\
$1: 3$ & 15 & 0,2901 & 0,2900 & 0,9130 & 0,414 & 0,065 & 0,178 & \\
$1: 4$ & 15 & 0,2594 & 0,2593 & 0,8660 & 0,477 & 0,075 & 0,185 & \\
\hline
\end{tabular}

Tabel 2. Parameter perlakuan terbaik

\begin{tabular}{ccc}
\hline No. & Parameter & Nilai \\
\hline 1 & Kadar glukosamin & $380,33 \mathrm{ppm}$ \\
2 & $\mathrm{pH}$ & 4,2 \\
3 & Rendemen & $13,69 \%$ \\
\hline
\end{tabular}

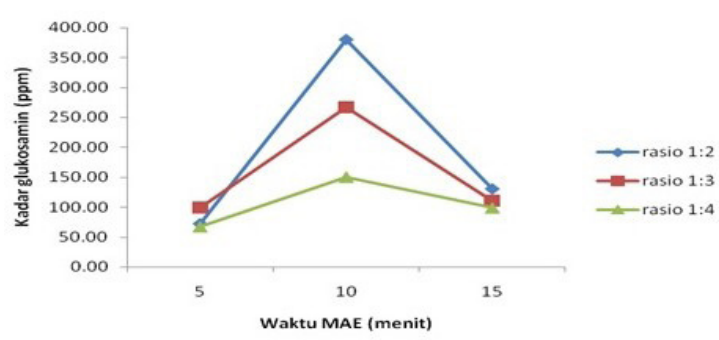

Gambar 1. Rerata kadar glukosamin biji buah siwalan

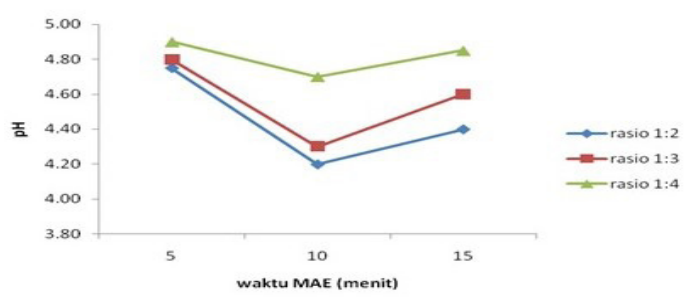

Gambar 2. Rerata pH glukosamin biji buah siwalan

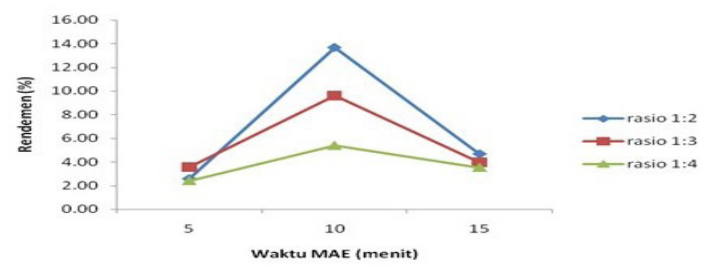

Gambar 3. Rerata rendemen glukosamin biji buah siwalan 
pembentukan glukosamin, dihasilkan ion $\mathrm{H}^{+}$yang berasal dari pemecahan ion ammonium. $\mathrm{pH}$ glukosamin dapat dipengaruhi $\mathrm{pH}$ bahan baku buah siwalan sebesar 6,7-6,9 (Alamelumangai et al., 2014; Jamkhande et al., 2016; A Surapsari, 2019)

\section{Rendemen Glukosamin}

Berdasarkan uji ANOVA menunjukkan bahwa faktor rasio bahan : pelarut dan waktu MAE memberikan pengaruh signifikan terhadap rendemen glukosamin. Uji lanjut DMRT menunjukkan bahwa masingmasing perlakuan pada kedua faktor memberikan pengaruh signifikan terhadap kadar glukosamin. Berdasarkan Gambar 3 rerata rendemen glukosamin berkisar antara 2,59\% sampai $13,69 \%$. Rendemen tertinggi dihasilkan dari perlakuan rasio 1:2 dan waktu ekstraksi 10 menit. Rasio bahan: pelarut semakin besar menyebabkan penurunan rendemen ekstrak. Hal ini sesuai dengan kadar glukosamin yang dihasilkan, dimana peningkatan konsentrasi menyebabkan kondisi rawan pada saat pre-treatment MAE. Hal ini dikarenakan peningkatan jumlah ion $\mathrm{H}^{+}$dan $\mathrm{Cl}^{-}$ pada saat pre-treatment MAE sehingga mengganggu proses pengikatan ion $\mathrm{NH}_{2-}$ dengan glukosa membentuk glukosamin. Hal tersebut mengakibatkan penurunan rendemen glukosamin yang signifikan.

Peningkatan waktu MAE hingga 10 menit menyebabkan peningkatan rendemen, namun rendemen mengalami penurunan ketika waktu pre-treatment MAE dilanjutkan hingga 15 menit. Hal ini terjadi karena dengan waktu ekstraksi 5 menit belum memberikan kesempatan ion $\mathrm{NH}_{2-}$ bereaksi sempurna dengan glukosa pada biji buah siwalan. Akan tetapi waktu ekstraksi dengan lama 15 menit akan menyebabkan ikatan antara glukosa dan ion $\mathrm{NH}_{2}$ terlepas sehingga menurunkan rendemen glukosamin. Hal ini sesuai dengan penelitian Magdalena dan Kusnadi (2015) bahwa rasio 1:45 menghasilkan rendemen ekstrak kasar daun gambir sebesar 78,18\%.

\section{Perlakuan terbaik}

Penentuan perlakuan terbaik ini dilakukan menggunakan metode Multiple Atributte yakni membangun data rata-rata hasil setiap pengujian. Adapun hasil penentuan terbaik dapat dilihat pada Tabel 1. Berdasarkan Tabel 1 diketahui bila perlakuan terbaik diperoleh pada perlakuan dengan rasio bahan : pelarut (1:2) dan lama waktu
MAE 10 menit, hal ini ditunjukkan dengan nilai L1, L2, dan Lmaks yang memiliki nilai paling minimum dari 9 perlakuan tersebut. Nilai L1, L2, Lmaks berturut-turut yaitu 0,$081 ; 0,006 ; 0,000$. Parameter perlakuan terbaik disajikan pada Tabel 2 .

\section{SIMPULAN}

Rasio bahan: pelarut dan waktu ekstraksi memiliki pengaruh yang signifikan terhadap kadar dan rendemen glukosamin, tetapi tidak memiliki pengaruh yang signifikan terhadap $\mathrm{pH}$ glukosamin. Perbandingan rasio dan waktu pre-treatment ekstraksi yang sesuai untuk menghasilkan glukosamin dengan kualitas terbaik adalah rasio bahan : pelarut (1:2) dan waktu ekstraksi 10 menit dengan rincian parameter kadar glukosamin 380,33 ppm, pH 4,2 dan rendemen $13,69 \%$.

\section{UCAPAN TERIMA KASIH}

Peneliti mengucapkan terima kasih kepada BPPM Fakultas Teknologi Pertanian Universitas Brawijaya yang telah membiayai penelitian ini melalui Dana Penerimaan Negara Bukan Pajak (PNBP) Universitas Brawijaya sesuai dengan Daftar Isian Pelaksanaan Anggaran (DIPA) Universitas Brawijaya Tahun 2018.

\section{DAFTAR PUSTAKA}

Alamelumangai, -M., Dhanalakshmi, -J., Mathumitha, -M., Renganayaki, R, -S., Muthukumaran, -P., Saraswathy, -N., 2014. In vitro studies on phytochemical evaluation and antimicrobial activity of Borassus flabellifer Linn against some human pathogens. Asian Pasific Journal of Tropical Medicine. 7(Supplement 1), S182-S185. https://doi.org/10.1016/ S1995-7645(14)60228-5

Cargill Incorporated. 2006. Application for the approval of the use REGENASURE® non-shellfish glucosamine hydrochloride from Aspergillus niger (RGHAN). Dilihat 20 Januari 2019. < https://acnfp.food.gov.uk/sites/de- 
Jurnal Teknologi Pertanian Vol. 20 No. 2 [Agustus 2019] 139-144

Produksi Glukosamin Biji Buah Siwalan (Borassus Flabellifer) [Rahmah dkk]

fault/files/mnt/drupal_data/sources/files/multimedia/pdfs/glucosamineappdossier.pdf>

Deo, S., Janghel, -A., Raut, -P., Bohsle, -D., Verma, -C., Agrawal, -M., Sharma, -M., Tripathi, D, -K., Alexander, -A., Kumar, -S., Amit, -N., Giri, -T., Ajaz, -A., 2015. Emerging microwave assisted extraction (MAE) techniques as an innovative green technologies for the effective extraction of the active phytopharmaceuticals. Research Journal of Pharmacy and Techology. 8(5), 655-666. https://doi. org/10.5958/0974-360X.2015.00104.3

Farida, -R., Nisa, F, -C., 2015. Ekstraksi antosianin limbah kulit manggis metode microwave assisted extraction (lama ekstraksi dan rasio bahan : pelarut). Jurnal Pangan dan Agroindustri. 3(2), 362-373. https://jpa.ub.ac.id/index.php/jpa/ article/view/152

Hajar, B, -K., 2016. Pembentukan glukosamin dari biji buah siwalan (Borassus flabellifer L.) (kajian jenis dan konsentrasi prekursor). Skripsi. Universitas Brawijaya. Malang

Horn, D, -E., Walker, L, -A., 2009. Introduction to General, Organic, and Biochemistry. Journal of Chemical Education.

Jarti, -N., Trisno, -R.,. 2017. Sistem pakar diagnosa penyakit alergi pada anak Berbasis web dengan metode forward chaining di kota Batam. Jurnal Edik Informatika. 3(2), 197-205. http://ejournal.stkippgri-sumbar.ac.id/index.php/eDikInformatika/article/download/2245/ pdf

Jamkhande, P, -G., Suryawanshi, V, -A., Kaylankar, T, -M., Patwekar, S, -L., 2016. Biological activities of leaves of ethnomedicinal plant, Borassus flabellifer Linn. (Palmyra palm): an antibacterial, antifungal and antioxidant evaluation. Bulletin of Faculty of Pharmacy, Cairo University. 54(1), 59-66. https://doi.org/10.1016/j. bfopcu.2016.01.002

Keerthi, -A., Jansz, - E., Ekanayake, -S., Premakumara, -G., 2009. The synergistic neurotoxins of palmyrah (Borassus flabellif- er). International Journal of Biological and Chemical Science. 3(2), 255-265. https:// doi.org/ 10.4314/ijbcs.v3i2.44488

Langat, M, -K., Nawrot, D, -A., Mulholland, D, -A., 2011. Chemical constituents of east european forest species. Pharmaceutical Biology. 50(5), 588.

Magdalena, N, -V., Kusnadi, -J.,. 2015. Antibakteri dari ekstrak kasar daun gambir (Uncaria Gambir Var Cubadak) metode microwave assisted extraction terhadap bakteri patogen. Jurnal Pangan dan Agroindustri. 3(1), 124-135. https:// jpa.ub.ac.id/index.php/jpa/article/ view/117

Mandal, -V., Mohan, -Y., Hemalatha, -S., 2007. Microwave assisted extraction - an innovative and promising extraction tool for medical plant research. Pharmacognosy Reviews. 1(1), 7-18. http://www. phcogrev.com/

Surapsari, -J., 2019. Manfaat Luar Biasa Buah Lontar, Salah Satunya Baik untuk Pencernaan. Dilihat 20 Januari 2019. < https://www.viva.co.id/gaya-hidup/ kesehatan-intim/1115856-manfaatluar-biasa-buah-lontar-salah-satunyabaik-untuk-pencernaan>

Rahmah, N, -L., Dewi, I, -A., Dewanti, B, S, -D., Perdani, C, -G., Setiyawan, D, -T., Ihwah, -A., Rohmah, W, -G., 2016. Studi optimasi reaksi pada ekstraksi crude glukosamin dari biji buah siwalan (Borassus Flabellifer L.). Jurnal Teknologi Pertanian. 1(17): 1-12. https://jtp.ub.ac.id/ index.php/jtp/article/view/553

Karmawati, -E., Memasso, -E., Ardana, -J., Ketut, -L., 2014. Tanaman Perkebunan Penghasil BBN. Diakses Tanggal 20 Oktober 2019. <http://lppm.ipb. ac.id/tanaman-perkebunan-penghasil$\mathrm{bbn} />$

Winata, E, -W., Yunianta. 2015. Ekstraksi antosianin buah murbei (Morus alba L.) metode ultrasonic bath (kajian waktu dan rasio bahan : pelarut). Jurnal Pangan dan Agroindustri. 3(2), 773-783. https:// jpa.ub.ac.id/index.php/jpa/article/ view/199 